\title{
INFLUENCE OF CLIMATE CHANGE ON THE GLOBAL CONDITION OF THE ENVIRONMENT AND AGRICULTURE IN THE OPINION OF RURAL YOUTH IN THE PODKARPACKIE PROVINCE
}

\author{
MARIAN WOŹNIAK
}

\begin{abstract}
The purpose of the article is to find out the opinions of rural youth regarding their awareness of climate change and the impact of this change on agriculture, and based on it, to determine whether these young people have adequate knowledge about global climate change.

This goal results from the fact that the world is more and more severely affected by the effects of climate change associated with a more frequent occurrence of extreme weather phenomena, air temperature increase, periodic drought and heat waves, violent hurricanes or melting glaciers. These changes, which are already beginning to take a stage of crisis, are mainly associated with the emission of greenhouse gases, and above all carbon dioxide, for which humanity is primarily responsible. It is therefore necessary to increase the awareness of rural residents, starting with children and young people, who in the near future will steer the development of regions and the world, about how great a threat are progressive climate changes to them, agriculture, and consequently to food security and human health. Young people currently need appropriate support from scientists and teachers who will help them understand and realize how important and necessary it is to undertake adaptation measures related to eliminating threats resulting from climate change, growing plant species more resistant to climatic conditions, protecting biodiversity, and water resources, forests and soil.

The article presents the causes and consequences of climate change in the light of research and public opinion, the impact of climate change on agriculture and the opinions of the surveyed rural youth from the Podkarpackie Province on contemporary climate change.
\end{abstract}

Keywords: climate change, global warming, agriculture, young people.

JEL codes: Q15, Q 51, Q54.

Marian Woźniak, DEng, DSc, Rzeszow University of Technology, Faculty of Management, Department of Economics; al. Powstańców Warszawy 12, 35-959 Rzeszów, Poland (mwozniak@prz.edu.pl).

ORCID iD: 0000-0003-4813-6612. 


\section{Introduction}

Scientists point out that the phenomena taking place on the Earth are very worrying, as over the past twenty years we have observed the highest temperatures since the time of making measurements and the highest concentration of $\mathrm{CO}_{2}$ in history. According to the most recent data of the World Meteorological Organization (WMO), presented in the report entitled Provisional Statement on the State of the Global Climate in 2019 (WMO, 2019b), 2010-2019 were the hottest years in the whole history of the Earth and 2019 was one of the top three hottest years in the whole history of measurements. Unfortunately, as the authors of the report claim: "our planet and the life on the Earth are at risk". Climate change results in the much more frequent violent weather phenomena which, in various parts of the world, have an essential influence also on agriculture, and consequently may destroy the achievements made by generations of farmers and have a negative impact on the life of residents. However, we must remember that in rural areas, there is a bilateral correlation, as climate change not only affects agriculture, but also agriculture contributes to climate change by emitting greenhouse gases. In order to reduce the emissions, we should pay more attention to a sustainable model of agriculture which provides the society with food of proper quality and we should remember that the modern economy, including agriculture, is responsible for providing food to more than seven billion people all over the world.

Climate is a common good and is to serve the whole global population. Therefore, the humanity should realise a need to change their lifestyles, production and consumption so as to stop or even eliminate the global warming. Climate change is a global problem and is one of the greatest challenges for humanity, while a significant increase in the concentration of carbon dioxide and other greenhouse gases is a fact and a result mainly of human activity, just as it was precisely verified in a publication entitled Climate science (Popkiewicz, Kardaś and Malinowski, 2019) where, based on the extensive scientific analysis, it was confirmed that the amount of carbon dioxide has been currently the largest for millions of years and that of methane and nitrous oxide for a million years.

Global climate change caused by an excessive amount of carbon dioxide and other greenhouse gases in the atmosphere may be currently called a crisis situation. Due to the development of human civilisation, the growing levels of harmful compounds in the atmosphere, depletion of non-renewable resources, spread of environmental pollution, occurrence of extreme weather phenomena becomes a fact and turns into a crisis (Moore, 2014) where climate change and its effects result in direct and indirect damage related to the impact on supply chains and a risk of economic shocks (Kabza, 2019).

The essence of this problem was also noticed by the Norwegian Nobel Committee in the field of economic sciences which demonstrated a multidisciplinary importance of this issue by awarding two economists, William Nordhaus and Paul Romer, in 2018 for the studies on the impact of economic development on climate, 
but also the studies on the impact of climate on economy, thus showing the importance of climate change in macroeconomy.

In this situation, the attitude of young people towards climate change becomes very important, as their views are significantly different from those of the older generation and in the future today's youth will determine the fate of our planet. Young people are those who will make decisions related to lifestyle, production, consumption, and consequently the emission of greenhouse gases in the near future.

Therefore, we should develop in young people proper ecological sensitivity, which can be already noticed in many situations, such as demonstrations for environmental protection, as well as make them realize that they cannot consider only financial aspects in economic activities, but also ecological values and knowledge and they should think about it today, so that they can act reasonably in the future and contribute to reduction of greenhouse gas emissions to a maximum level.

\section{Methodology and objective of the study}

The objective of the article is to know the opinions of rural young people on their awareness regarding climate change and the impact of climate change on agriculture, and to conclude, based on these opinions, whether young people have a proper knowledge about global warming.

The article presented the following research hypotheses:

- according to the young people from the Podkarpackie Province, climate change is currently one of the greatest risks to modern civilisation;

- according to the surveyed young people, extreme weather phenomena result mostly from climate change;

- according to the young people from the Podkarpackie Province, climate change has a negative impact on agriculture.

This was a partial study, as the detailed analysis covered only part of the population of young people from the Podkarpackie Province, which includes persons aged 15-24, according to the study by the Chancellery of the Prime Minister (Szafraniec and Boni (ed.), 2011).

Taking into account time and organisational limitations of the studies, it was decided that the studied population would be pupils of two secondary schools in Rzeszów and students of the Faculty of Management at the Rzeszow University of Technology. The selection of the study sample was purposive, as for the studies we selected two secondary schools highly popular with rural and urban young people from the Podkarpackie Province, and first year students of the Faculty of Management at the Rzeszow University of Technology, where mostly urban and rural young people from the Podkarpackie Province study. A preliminary study confirmed that in those units $45 \%$ of young learners live in rural areas of the Podkarpackie Province, as documented in the statistics on persons admittedf to first grade and first year of full-time studies. 
The selection of those units gives rise to conclude that they are representative of the whole population of young people in the province.

The studies on the opinions of young people on climate change and its impact on environment and agriculture were conducted in the first months of 2019 and 2020 , on a sample of 1,103 persons. Out of the number of properly completed questionnaires, the surveys completed by the urban young people were rejected and 484 surveys completed exclusively by the rural young people from the Podkarpackie Province were eligible for a detailed analysis.

In the case of the analysis in groups by sex, no statistically significant differences were found, so they are not shown in the detailed characteristics.

The empirical data was collected based on the survey consisting in obtaining information from the young people, using a questionnaire while for measuring the attitudes towards specific opinions a5-point, bipolar Likert scale was used which means that a respondent could choose a middle value or an opposite answer on both sides.

\section{Reasons and consequences of climate change in the light of studies}

As reported by the WMO in The State of Greenhouse Gases in the Atmosphere Based on Global Observations through 2018 (WMO, 2019a), the global concentration of $\mathrm{CO}_{2}$ in 2018 reached the level of $407.8 \mathrm{ppm}$ which accounted for $147 \%$ of the value in 1750 , i.e. before intense industrialisation. The report also highlighted that the increased levels of other greenhouse gases, such as methane (CH4) and nitrous oxide $\left(\mathrm{N}_{2} \mathrm{O}\right)$ had also been recorded in the atmosphere. The level of methane in the atmosphere reached the value of $1,869 \mathrm{ppb}$, constituting for $259 \%$ of the value in 1750, whereas the level of nitrous oxide was $331.1 \mathrm{ppb}$, i.e. $123 \%$ of the pre-industrial era level. As stressed by the WMO members, in 2018 the concentration of greenhouse gases in the atmosphere reached a record-breaking level, and the largest emitters of $\mathrm{CO}_{2}$ on the global scale are China, the USA, India, Russia and Japan (Table 1). Poland was ranked eighteenth in this inglorious ranking. But is the society, in particular youth, aware of this fact and does it know about the scale of this phenomenon?

If the EU-28 was regarded asa single country, it would be ranked third on a global scale, after China and the USA, in terms of the $\mathrm{CO}_{2}$ emissions. The top three largest emitters in the EU included Germany, the United Kingdom, and Poland which, according to the Eurostat data, is indicated as one of the major greenhouse gas emitters in Europe. Yet in fact, it is not responsible for their largest emission, which is attributed to Germany. This is related to the fact that in 2018 this country emitted 759 million tonnes of greenhouse gases, i.e. it was responsible for $22 \%$ of total emission in the whole EU, followed by: the United Kingdom (11\%), Poland (9.98\%), France $(9.8 \%)$ and Italy $(9.8 \%)$. 
The largest emitters of $\mathrm{CO}_{2}$ in the world in 2018

Table 1

\begin{tabular}{|c|c|c|c|c|c|c|c|}
\hline \multirow{2}{*}{$\begin{array}{l}\text { :0 } \\
.0 \\
0 \\
0 \\
0\end{array}$} & \multicolumn{2}{|c|}{$\begin{array}{l}\text { Largest global emitters of } \mathrm{CO}_{2} \\
\text { (million } \mathrm{MgCO}_{2} / \text { year) }\end{array}$} & \multicolumn{2}{|c|}{$\begin{array}{l}\text { Largest global emitters per } \\
\text { capita }\left(\mathrm{MgCO}_{2} \text { per capita }\right)\end{array}$} & \multicolumn{3}{|c|}{$\begin{array}{l}\text { Largest emitters in the European } \\
\text { Commission (million } \mathrm{MgCO}_{2} / \text { year) }\end{array}$} \\
\hline & Country & Total & Country & & Country & Total & Per capita \\
\hline 1 & China & 10,065 & Qatar & 38 & Germany & 759 & 9.1 \\
\hline 2 & USA & 5,416 & Curacao & 34 & United Kingdom & 379 & 5.6 \\
\hline 3 & EU-28 & 3,445 & Trinidad and Tobago & 31 & Poland & 344 & 9.1 \\
\hline 4 & India & 2,654 & Kuwait & 24 & France & 338 & 5.2 \\
\hline 5 & Russia & 1,711 & United Arab Emirates & 21 & Italy & 338 & 5.6 \\
\hline 6 & Japan & 1,162 & New Caledonia & 21 & Spain & 268 & 5.7 \\
\hline 7 & Iran & 720 & Bahrain & 20 & Netherlands & 162 & 9.5 \\
\hline 8 & South Korea & 659 & Brunei & 19 & Czech Republic & 106 & 9.9 \\
\hline 9 & Saudi Arabia & 621 & Saudi Arabia & 18 & Belgium & 100 & 8.7 \\
\hline 10 & Indonesia & 615 & Kazakhstan & 18 & Romania & 74 & 3.5 \\
\hline
\end{tabular}

Source: own study based on: Global Carbon..., 2020.

In 2017, carbon dioxide in Poland was responsible for $81 \%$ of the impact on strengthening the greenhouse effect in the country and the major anthropogenic source of $\mathrm{CO}_{2}$ emission were fuel burning processes, i.e. $93 \%$ of total emissions, including the energy sector (49\%), transport (19\%), production and building sectors $(9 \%)$. The major source of ammonia emission was agriculture $-94 \%$ of total emissions, mainly related to faeces of livestock and consumption of nitrogen fertilisers (CSO, 2019).

In the article published in 2018 entitled Trajectories of the Earth System in the Anthropocene (Steffen et al., 2018) scientists examining global climate change present the facts showing that we are closer and closer to exceeding the safety threshold related to the global temperature increase by $2^{\circ} \mathrm{C}$. This warming may result in crossing the invisible line, called the temperature critical point, after which the stabilisation of the Earth's climatic system will be almost impossible.

Critical points are related to a significant reduction of polar cap in the Arctic (Stroeve et al., 2012) and shrinking of ice sheets in Greenland (Hanna et al., 2013), withdrawal of mountain glaciers in the world (Yao et al., 2012), expansion of the drought zone and heatwaves (Dai, 2013), decreased population of anthozoans (Hoegh-Guldberg et al., 2007) and changes in habits and places of living of certain wild species (Parmesan, 2006) and, as a consequence, also to a crisis regarding food security of humans.

As pointed out by Lenton et al. (2019), in the case of nine out of fifteen important large-scale phenomena resulting from climate change we are already dangerously approaching the situation where critical points are crossed, due to which climate change will become unstoppable and irreversible (Fig. 1). 


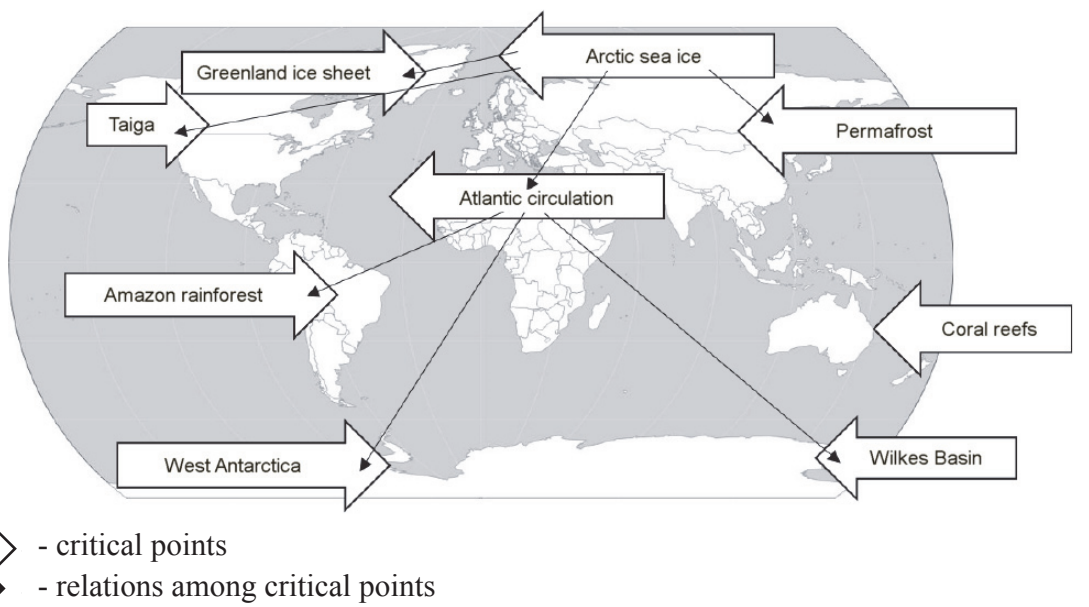

Fig 1. Critical points particularly exposed to climate change.

Source: Lenton et al., 2019.

The authors stress that avoiding the crossing of critical points related to the dying out of Amazon rainforests, in combination with frequent droughts, fires and dying out of insects, meltdown of permafrost, disappearance of ice in the Arctic, withdrawal of glaciers in Greenland and West Antarctica as well as coral bleaching is dictated by a need to strongly limit, and ideally stop, emission of greenhouse gases, also those related to emission in agriculture (Saunois, Jackson, Bousquet, Poulter and Canadell, 2016).Obviously, it is hardly possible as it would mean abandonment of agricultural activities and, as a consequence, stopping the production of food.

According to the most pessimistic forecasts related to global climate change, they will contribute to decreasing global GDP at the end of the 21 st century by even $8.6 \%$, while in a situation of achieving all goals adopted in the Paris Agreement of 2015, the negative economic impact will decrease only by less than $1 \%$ of global GDP (Kabza, 2019). However, in order to achieve these goals, the Polish Ministry of Climate announced that the cost of achieving climate neutrality by Poland may entail incurring further investments amounting to $1-3 \%$ of GDP which, in fact, translates into the amount of EUR 400 billion in the years 2021-2050 (Kurtyka, 2020).

The report entitled Weather, Climate \& Catastrophe Insight (2019) stressed that in 2019, on the global scale, there were 409 natural disasters mostly related to climate change, which resulted in losses estimated at USD 232 billion, of which 71 billion regarded payment of compensation. Only five of the most costly disasters related to floods in the USA, China, India and Iran cost more than USD 53 billion of direct economic impact. In Poland, droughts taking place in 2019 burdened the economy with an amount of PLN 2.6-3 billion and significantly translated into a $5 \%$ rise in prices of food.

In addition, it is stressed that the occurrence of drought in each year may result in the so-called snowball effect related to the fact that recurrent droughts lead to desertification of soils (Domański, 2020). 


\section{Climate change in public opinion}

According to global scientific organisations and academies of science from 80 countries worldwide (including Poland), it is humans who are mainly responsible for global warming and $97 \%$ of climatologists publishing papers on reasons for climate change are of opinion that all people and their socio-economic activities cause global warming and its effects which can now be observed (Popkiewicz, 2013). Nearly $100 \%$ of scientific papers on climate change indicate that society is mainly responsible for this change and the increased emission of greenhouse gases was triggered not only by combustion of fossil fuels, but also intensive land use, deforestation or drying of wetland. Therefore, we should refute a conclusion that climate warming results mainly from natural processes, because volcano eruptions emit only 0.3 billion tonnes of $\mathrm{CO}_{2}$ a year which accounts only for $1 \%$ of total global emission (Polityka..., 2018).

This is how climate change is assessed by scientists and how is it assessed by the society?

According to studies by the European Investment Bank (EIB) of 2018 on climate change, $75 \%$ of the surveyed Poles are worried about climate change and its consequences. Even a greater difference can be observed with regard to the risk assessment, as $40 \%$ of the surveyed Poles are of opinion that climate change is already a threat to humanity, whereas $59 \%$ of respondents from the EU are of a similar opinion. The survey showed that climate change is more worrying for young people and society in the southern Europe which does not correspond to the opinion of the Polish young people, in the case of whom only $34 \%$ state that climate change is a threat to the population, when compared to $48 \%$ of the older generation. The results of the EIB survey showed that residents of the European Union are more worried about climate change (78\%) than the Chinese $(65 \%)$ and American $(63 \%)$ societies (EBI..., 2018).

From the surveys of the Public Opinion Research Centre, it results that the majority of the Polish society definitely regard climate change as a phenomenon harmful to the future of people and of the Earth, however, 54\% state that climate change is only one of many threats, in addition to terrorism and cyberattacks. Only one third of the Poles state that climate change is definitely the greatest threat to the modern world and $75 \%$ of the respondents regard it as an effect of actions of all people (Polacy..., 2018).

According to the Countryside in Poland 2017 report (Sadura, Murawska and Włodarczyk, 2017), rural residents realise that climate change and the growing probability of extreme weather phenomena and their severity are important factors which have already influenced the image of rural areas and agriculture of the $21^{\text {st }}$ century and in the nearest future will shape this image even more.

\section{Impact of climate change on agriculture}

Pursuant to the guidelines of the European Environment Agency, preparing for climate change should become a priority for the agricultural sector in the EU. The Agency emphasises how important and necessary it is to increase awareness 
of society and how serious a threat is climate change for rural areas and agriculture and that the agricultural sector is strongly dependent on weather and climate conditions. The EEA experts point to the fact that climate change may also have positive consequences related to the extension of growing seasons and that agriculture still remains one of the driving forces of climate change.

Agriculture significantly contributes to greenhouse gas emissions and is responsible for $12-14 \%$ of their emission depending on the source. It should also be added that the warming potential of nitrous oxide is 290 times greater than that of carbon dioxide while the warming potential of methane is 25 times greater. In Poland and in the EU, agriculture is responsible for $10 \%$ of greenhouse gas emissions and for even $25-35 \%$ of global emissions when taking into account the whole food production chain related to processing, storage, transport and waste, (Rogala, 2020).

Recognising the problem of the impact of climate change on rural areas, the European Commission implements the Financial Instrument for the Environment and Climate Action programme (LIFE) in which it explains how to adapt agriculture and forestry to global climate change by means of a slogan "Ready, steady, green!" (Bellon, 2019).

Climate change has significant agricultural impacts, both direct and indirect (Tubiello, Soussana and Howden, 2007). The direct impact mainly refers to climate change shaping the yield. The direct impact is related to the impact of the higher concentration of $\mathrm{CO}_{2}$ on the crop productivity and efficient use of aquatic and nutritive resources, the impact of temperature changes and solar radiation on the growth of plants and the amount of yields and losses caused by extreme weather phenomena (Kundzewicz and Kozyra, 2011). The indirect impact is a consequence of dependence of plants on factors induced by climate change, changes in the use of individual crops in a given location, specificities of plant nutrition and pest and disease occurrence as well as changes in the environmental response by destroying the physical system such as soil erosion (Tubiello et al., 2007).

By showing the agricultural impact of climate change, we may mainly point out to changes in weather conditions related to the disappearance of current seasons and evolution towards two seasons only: cool and rainy winter as well as dry and hot summer, extreme weather phenomena combined with hailstorm, violent storms, hurricanes, floods and droughts, changes in hydrographic conditions associated with snowless winters, water deficits in the period of plant sprouting in spring as well as invasive species related to ousting old, "traditional" plant and animal species and pest invasions (Sękowski, 2014). The impact of climate change on agriculture may be both negative and positive (Table 2). 
Impact of climate change on agriculture

Table 2

\begin{tabular}{|c|c|}
\hline Positive changes & Negative changes \\
\hline - acceleration of spring field work & - limited water availability \\
\hline • prolonged growing period & - loss of carbon in soil \\
\hline $\begin{array}{l}\text { - introduction of new varieties and } \\
\text { species of crops }\end{array}$ & - deterioration of soil conditions related to water deficit, soil cracking \\
\hline - effect of enhancing the atmosphere & droughts \\
\hline $\begin{array}{l}\text { with carbon dioxide, which is } \\
\text { positive for plants }\end{array}$ & $\begin{array}{l}\text { - damage to crops related to the more frequent occurrence of extreme } \\
\text { weather phenomena }\end{array}$ \\
\hline - limited occurrence of some & - changes in the range of invasive pests and diseases \\
\hline pests & - changes in the productivity and vitality of forests \\
\hline - more efficient use of water in & - increased risk of fires \\
\hline plants & - imbalance of nutrients in soil \\
\hline $\begin{array}{l}\text { - faster development and higher } \\
\text { yields }\end{array}$ & $\begin{array}{l}\text { - distortion of local (traditional) food production conditions, forcing } \\
\text { changes in cultivation systems }\end{array}$ \\
\hline \multirow{2}{*}{$\begin{array}{l}\text { - extension of the grazing season } \\
\text { - increased yields of thermophilic } \\
\text { plants (sunflower, maize) }\end{array}$} & $\begin{array}{l}\text { - limited area of crops cultivated in cool and humid climate } \\
\text { (potatoes) }\end{array}$ \\
\hline & $\begin{array}{l}\text { - increased occurrence of various pests and their appetite related to } \\
\text { accelerated metabolism. }\end{array}$ \\
\hline
\end{tabular}

Source: based on: European Climate Change Programme, Working Group II Impacts and Adaptation, Agriculture and Forestry, (2006). Sectoral Report, European Commission. Downloaded from: https://ec.europa. $\mathrm{eu} / \mathrm{clima} /$ sites/clima/files/eccp/second/stakeholder/docs/agriforestry_en.pdf (5.3.2020).

We must remember that climate change has an impact on agriculture, but at the same time agriculture contributes to climate change, which is related mainly to emission of $\mathrm{CO}_{2}, \mathrm{~N}_{2} \mathrm{O}$ and $\mathrm{CH}_{4}$ (Fig. 2).

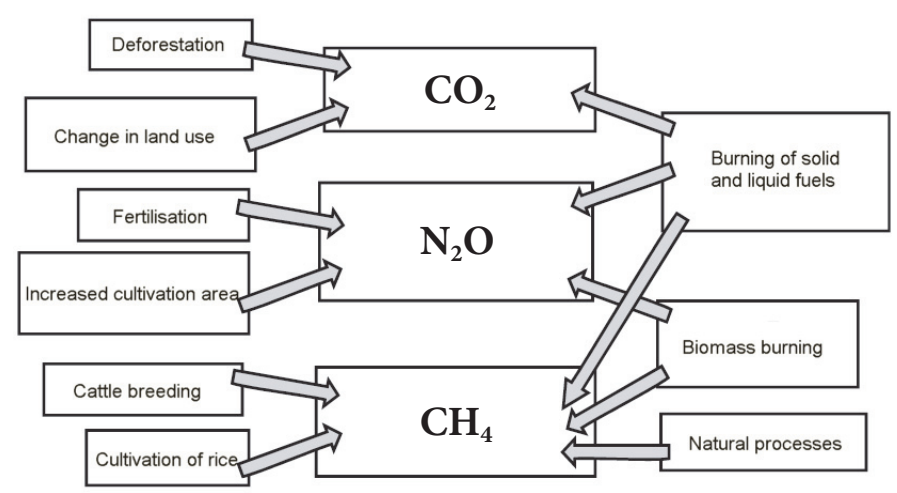

Fig. 2. The impact of activity of rural residents on greenhouse gas emissions in rural areas and agriculture.

Source: Bański and Błażejczyk, 2005. 
The greenhouse gas emissions originating in agriculture are mostly related to direct farming, animal faeces and intestinal fermentation in cattle.

In 2016, emissions of greenhouse gases from the agricultural sector in Poland amounted to $7.6 \%$ of total emission whereby the largest emission was related to agricultural soils (42.9\%), intestinal fermentation (41.9\%), fertiliser management $(12.5 \%)$, liming and application of urea (1.3\% each) and burning residues on fields (0.1\%) (Diagnoza ..., 2019).

Agriculture is severely affected by climate change effects, but also contributes to this change, by exerting a direct or an indirect impact on many sectors of rural economy, through a physical and biological impact on the components of ecosystems, mainly on water, soil, air and biodiversity. However, we can observe the greatest impact in the agricultural sector where climate change has a significant impact on yields, animal husbandry or production location, as well as on animal welfare and plant health with respect to water quality and availability which plays an essential role in agriculture. It is estimated that for more than $80 \%$ of the agricultural crop area, yields are highly dependent on the amount and distribution of rainfall and, unfortunately, it is forecast that by 2070 water deficient areas in Europe will have increased from $1 \%$ to $35 \%$ (KLIMADA, 2019) which will also contribute to an increased risk related to the agricultural production.

According to the European Environment Agency, in some parts of Europe climate change may result in an decreased cultivation of plants and livestock production or even their abandonment. The Agency highlights that when examining forecasts based on the scenario of the highest emission of greenhouse gases, the yields of wheat, maize and sugar beet will have decreased in the southern Europe even by $50 \%$ by 2050 and even by $80 \%$ by 2100 which, consequently, may contribute to a significant decrease in farms' income. The EEA experts state that the situation is much worse on farms where farmers either have no appropriate knowledge about the climate change, so as to prepare for it, or make nothing of it (Zmiany klimatu..., 2019).

The authors of the report entitled Climate Change. Agricultural Impact and Costs of Adaptation state that climate change will have a particularly strong impact on the crop production in Sub-Saharan Africa and South Asia where it will result in decreased production of rice by $14-15 \%$, maize by $9-19 \%$, and wheat by $34-49 \%$. The report also read that in the period of 2000-2050, even without climate change, the prices of rice will rise by $62 \%$, maize by $63 \%$ and wheat by $39 \%$. Climate change will also result in the price rise by $32-37 \%$ for rice, $52-55 \%$ for maize and as much as $94-111 \%$ for wheat. The prices of beef will be higher by $33 \%$ and in the case of climate change by additional $60 \%$ (Nelson et al., 2009).

According to the Ministry of Agriculture and Rural Development data, the 2018 drought affected 130 thousand farms in Poland which resulted in destroying 3.5 million ha of crops (Kowalczyk, 2018) while due to drought in the spring of 2019 the prices of food rose by several tens of percent which affected the society severely. 
For example, in the years $2018-2019$, onions went up in price by $60 \%$, potatoes by $55 \%$, celeriac by $44 \%$, beets by $31 \%$. According to the CSO, in 2019 the retail prices of field vegetables rose on average by $20 \%$ (Szymański, 2020).

From the report of April 2020, it results that more than one third of Polish areas struggled with agricultural drought. However, it was shown that, on a national scale, the Podkarpackie Province under threat of drought to a small extent, compared to the Wielkopolskie Province where the risk was the greatest and the most extreme (Zagrożenie..., 2020). In the early summer following the spring drought, in the Podkarpackie Province, there were violent storms with hailstorms and local floods which had a negative impact on the local society and on agriculture.

The negative impacts of climate change may also be observed in forestry management and are related, first and foremost, with changes in the productivity of forests, geographical range of individual tree species and distortions in shaping the area of forests, related to more frequent fires and the presence of pests.

The report entitled The European Environment - State and Outlook 2020 (EEA, 2019) shows that climate change also has an impact on biodiversity which can be observed in changes in the distribution of species, size of the population, reduced time of reproduction, migration and increased number of pests and diseases. A very distinct example of climate change is the extinction of pollinators such as bees and the emergence of invasive species. According to a comprehensive overview of 73 scientific reports, presented in the Biological Conservation journal, the decreased population of insects has an impact on biodiversity and is a threat to the whole world. As a major reason for the extinction of insects, the loss of habitats is mentioned, due to transition to intensive agriculture and agrochemical pollution, invasive species and climate change (Sanchez-Bayo and Wyckhuys, 2019).

\section{Climate change in the opinion of the rural youth from the Podkarpackie Province}

The opinions of the surveyed young people living in rural areas of the Podkarpackie Province, which allow us to know their attitudes towards climate change, have been presented in Table 3.

When analysing the assessment of climate change in the opinion of the young people from the Podkarpackie Province, it can be stated that the surveyed young people understand the nature of the problem, as $24.2 \%$ recognise it definitely as one of the largest threats to modern civilisation and $54.4 \%$ as an important threat. Also, these young people think that climate change is one of many contemporary threats as more than $90 \%$ of the respondents are of this opinion. A positive aspect is the fact that more than $50 \%$ of the surveyed young people still think that climate change is not advanced to an extent where it would be impossible to reverse its effects and correct errors of the past. The surveyed young people are of opinion that climate change is mainly caused by human activity. This is stated by more than $85 \%$ of the respondents, whereas nearly $50 \%$ also think that climate change is a natural phenomenon. 
Climate change in the opinion of the rural youth

Table 3

\begin{tabular}{|c|c|c|c|c|c|}
\hline \multirow{3}{*}{ Assessment of climate change } & \multicolumn{5}{|c|}{ Possible answers } \\
\hline & $\begin{array}{l}\stackrel{0}{0} \\
\frac{\lambda}{2} \\
\stackrel{0}{\Xi} \\
\stackrel{0}{0} \\
0\end{array}$ & 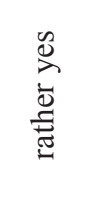 & 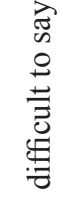 & 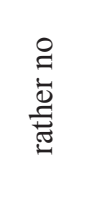 & 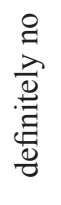 \\
\hline & \multicolumn{5}{|c|}{$\%$ of answers } \\
\hline $\begin{array}{l}\text { Climate change is currently one of the largest threats } \\
\text { to modern civilisation }\end{array}$ & 24.2 & 54.4 & 7.0 & 10.1 & 4.2 \\
\hline $\begin{array}{l}\text { Climate change is a certain threat but is one of many } \\
\text { dangerous phenomena }\end{array}$ & 40.5 & 50.6 & 2.3 & 1.9 & 4.7 \\
\hline $\begin{array}{l}\text { Climate change is so advanced that its effects } \\
\text { cannot be reversed }\end{array}$ & 7.4 & 18.6 & 22.8 & 42.8 & 8.4 \\
\hline Climate change is a natural phenomenon & 15.8 & 34.0 & 19.5 & 21.9 & 8.8 \\
\hline Climate change is caused by human activity & 40.0 & 45.1 & 6.5 & 4.2 & 4.2 \\
\hline
\end{tabular}

Source: own studies.

When responding the question regarding the state of natural environment (Table 4), $60 \%$ of the surveyed persons stated that the environment of the Podkarpackie Province is a reason for concern and worry to a small extent while one fourth of the respondents stated that it causes concerns to a large extent. The state of natural environment in Poland was assessed completely different; more than $50 \%$ of the respondents think that it is a reason for concern and worry to a large extent and the situation in the world was assessed even worse where more than $80 \%$ of the surveyed young people stated that the state of environment is a reason for concern and worry for the modern generation to a large or very large extent.

Table 4

Assessment of the state of the natural environment in the opinion of the rural youth

\begin{tabular}{|c|c|c|c|c|c|}
\hline \multirow{3}{*}{$\begin{array}{l}\text { State of the natural environment is a } \\
\text { reason for concern and worry }\end{array}$} & \multicolumn{5}{|c|}{ Possible answers } \\
\hline & 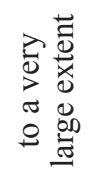 & 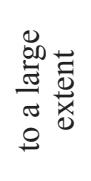 & 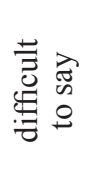 & 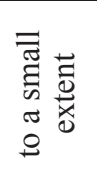 & 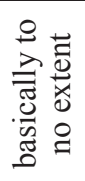 \\
\hline & \multicolumn{5}{|c|}{$\%$ of answers } \\
\hline in the Podkarpackie Province & 3.5 & 20.5 & 10.2 & 59.1 & 6.5 \\
\hline in Poland & 7.0 & 52.5 & 2.8 & 32.1 & 5.6 \\
\hline in the world & 41.9 & 41.9 & 1.7 & 10.3 & 4.2 \\
\hline
\end{tabular}

Source: own studies. 
When responding the question on the agricultural impact of climate change (Table 5), similarly as in the case of the assessment of the state of natural environment, nearly $70 \%$ of the respondents stressed that with regard to the Podkarpackie Province climate change has no significant impact on agriculture. On the other hand, the impact of climate change on agriculture in Poland and in the world was assessed differently, yet not so drastically as the state of natural environment. With regard to Poland, more than one third of respondents stated that it is difficult to demonstrate a significant relation but with regard to the world $36.3 \%$ of respondents paint a gloomy picture of the state of the natural environment worldwide stating that climate change has definitely a negative impact on global agriculture while $24.2 \%$ of them state that it has rather a negative impact.

Table 5

Assessment of the impact of climate change on agriculture in the opinion of the rural youth from the Podkarpackie Province

\begin{tabular}{|c|c|c|c|c|c|}
\hline \multirow{3}{*}{$\begin{array}{c}\text { Climate change has a negative } \\
\text { agricultural impact }\end{array}$} & \multicolumn{5}{|c|}{ Possible answers } \\
\hline & 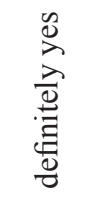 & 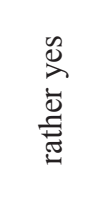 & 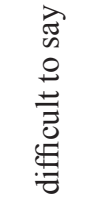 & 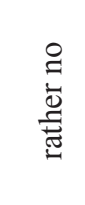 & 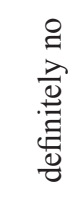 \\
\hline & \multicolumn{5}{|c|}{$\%$ of answers } \\
\hline in the Podkarpackie Province & 0.3 & 1.2 & 24.7 & 68.2 & 5.6 \\
\hline in Poland & 1.8 & 9.8 & 38.5 & 40.1 & 10.3 \\
\hline in the world & 36.3 & 24.2 & 26.4 & 7.8 & 5.6 \\
\hline
\end{tabular}

Source: own studies.

The studies also allowed us to determine the opinions of the rural youth from the Podkarpackie Province on the selected statements related to climate change (Table 6).

With regard to the statement that there is no empirical evidence for anthropogenicity of global warming, $43.4 \%$ of respondents mostly stated that it is difficult to say while $39.1 \%$ agreed with this statement. The situation was similar in the case of the statement that global warming is an effect of an urban heat island related to asphalt and concrete infrastructure. $68.4 \%$ of the respondents agreed with the statement that carbon dioxide emitted by all people is of no importance for the environment.

The results of the study show that more than $70 \%$ of young people disagree with the statements that there is no global warming and that global warming, even if it occurs, will not have such a negative impact. More than $50 \%$ of the surveyed young people disagree with the statement that breathing causes huge emissions of carbon dioxide, moreover, extreme weather phenomena are not related to global 
warming and in order to combat global warming, it is enough to plant more trees. Nearly $40 \%$ of respondents agree with the statement that volcanoes emit more carbon dioxide than the society which is in contradiction with scientific data.

Table 6

Statements related to climate change in the opinion of the rural youth

from the Podkarpackie Province

\begin{tabular}{|c|c|c|c|c|c|}
\hline Statements on climate change & 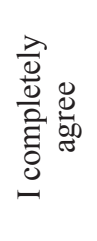 & 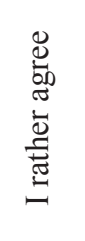 & 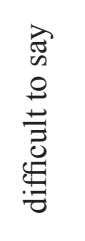 & 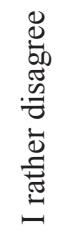 & 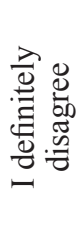 \\
\hline & \multicolumn{5}{|c|}{$\%$ of answers } \\
\hline $\begin{array}{l}\text { There is no empirical evidence for anthropogenicity } \\
\text { of global warming (caused by human activity only) }\end{array}$ & 6.0 & 11.2 & 43.4 & 16.5 & 22.6 \\
\hline There is no global warming & 2.6 & 4.1 & 16.5 & 16.8 & 60.0 \\
\hline $\begin{array}{l}\text { Carbon dioxide emitted by all people is of no importance } \\
\text { for the environment }\end{array}$ & 6.0 & 14.6 & 14.6 & 22.8 & 42.0 \\
\hline Breathing causes huge emissions of $\mathrm{CO}_{2}$ & 3.4 & 12.4 & 27.3 & 35.2 & 21.7 \\
\hline Volcanoes emit more carbon dioxide than society & 16.5 & 23.2 & 39.3 & 11.9 & 9.1 \\
\hline $\begin{array}{l}\text { Global warming, even if it occurs, will not have such } \\
\text { a negative impact }\end{array}$ & 4.1 & 8.6 & 16.5 & 26.6 & 44.2 \\
\hline $\begin{array}{l}\text { Extreme weather phenomena are not related to global } \\
\text { warming }\end{array}$ & 5.9 & 12.7 & 26.9 & 26.9 & 27.6 \\
\hline $\begin{array}{l}\text { Global warming is an effect of an urban heat island } \\
\text { (related to asphalt and concrete infrastructure) }\end{array}$ & 5.9 & 24.7 & 43.1 & 18.0 & 8.3 \\
\hline $\begin{array}{l}\text { In order to combat global warming, it is enough } \\
\text { to plant more trees }\end{array}$ & 3.7 & 17.2 & 26.6 & 32.9 & 19.6 \\
\hline
\end{tabular}

Source: own studies.

\section{Summary}

The climate change, which can now be observed, is currently unquestionable and indicated as one of major threats not only to the global environment, but also to social and economic values of humanity. Practically speaking, the definite majority of organisations and scientists dealing with climate agree with the statement that climate change has already become a fact and is of anthropogenic nature.

From the results of the surveys conducted among the rural youth from the Podkarpackie Province, we may draw the following conclusions:

- the surveyed young people think that climate change is currently one of the largest threats to modern civilisation, while stating that it is not the only but one of many threats and is not so advanced to be irreversible or even unstoppable; 
- the young people believe that it is, first and foremost, all humans living on the Earth who are responsible for climate change;

- opinions of the surveyed young people confirm that they positively assess the state of natural environment in the Podkarpackie Province, whereas the state of environment in Poland is a reason for concern and worry to a great extent and the state of environment in the world raises concerns to the largest extent.

- the surveyed young people had a similar opinion with regard to the assessment of the impact of climate change on agriculture: the impact of climate change on global agriculture was assessed as the worst and the impact on agriculture in the Podkarpackie Province as the best;

- the surveyed representatives of young people disagreed with the statement that there is no global warming and that extreme weather phenomena are not related to global warming.

The results of the analysis of the opinions allow us to conclude that the presented scientific hypotheses have been verified positively(according to the young people from the Podkarpackie Province climate change is currently one of the largest threats to modern civilisation and according to the surveyed young people extreme weather phenomena result mainly from climate change). In turn, the hypothesis that climate change has a negative impact on agriculture in the opinion of the youth from the Podkarpackie Province, remains ambiguous, as the opinions depended on the region. As for the impact on global agriculture, the hypothesis has been verified positively, whereas in the case of the impact on agriculture in the Podkarpackie Province the hypothesis has been verified negatively.

To sum up, we may conclude that the partial fault related to a quite high percentage of answers "difficult to say" to some questions in the survey results from the absence of a proper educational system which, to a large extent, would highlight climate change and resulting consequences and stimulate young people to discuss these issues. It is necessary to educate rural youth more and make them realise that all actions related to climate protection and reduction of greenhouse gas emissions are taken also in their interest, as future farmers. 


\section{References}

Bański, J., Błażejczyk, K. (2005). Globalne zmiany klimatu - wpływ na rozwój rolnictwa na świecie. In: G. Dybowski (ed.) Wpływ procesu globalizacji na rozwój rolnictwa na świecie (pp. 206-233). Program Wieloletni 2005-2009, No. 17. Warszawa: IERiGŻ-PIB.

Bellon, M. (2019). Zmiana klimatu zagraża rolnictwu w UE. Na poludniu Europy uprawa może w ogóle ustać. Retrieved from: https://businessinsider.com.pl/wiadomosci/zmiana-klimatu-i-jej--wplyw-na-rolnictwo-w-europie-raport-eea/r3hfthl (access date: 6.9.2019).

Dai, A. (2013). Increasing Drought under Global Warming in Observations and Models. Nature Climate Change, Vol. 3, pp. 52-58. DOI: 10.1038/nclimate1633.

Diagnoza sytuacji społeczno-gospodarczej rolnictwa, obszarów wiejskich i rybactwa w Polsce (2019). Warszawa: Ministerstwo Rolnictwa i Rozwoju Wsi.

Domański, T. (2020). Właśnie się zaczęła największa susza od lat. Polacy boleśnie odczuja własne zaniedbania. Retrieved from: https://spidersweb.pl/2020/04/susza-w-polsce-2020. html (access date: 28.4.2020).

EBI Climate Survey (2018). Polacy sa mniej zaniepokojeni zmiana klimatu niż inne na-rody europejskie. Retrieved from: https://nowa-energia.com.pl/2018/11/09/ankieta-ebi-dotyczaca--klimatu-polacy-sa-mniej-zaniepokojeni-zmiana-klimatu-niz-inne-narody-europejskie/ (access date: 9.11.2018).

EEA (2019). The European Environment - State and Outlook 2020. Knowledge for Transition to a Sustainable Europe. European Environment Agency2019, Copenhagen Denmark. pp. 72-92. Retrieved from: https://www.eea.europa.eu/publications/soer-2020 (access date: 5.5.2020).

European Climate Change Programme, Working Group II Impacts and Adaptation, Agriculture and Forestry, Sectoral Report (2006). European Commision. Retrieved from: https://ec.europa. eu/cli$\mathrm{ma} /$ sites/clima/files/eccp/second/stakeholder/docs/agriforestry_en.pdf (access date: 15.01.2020).

Global Carbon Atlas. $\mathrm{CO}_{2}$ Emission. Retrieved from: http://globalcarbonatlas.org/en/ $\mathrm{CO}_{2}$ emissions (access date: 15.5.2020).

GUS (2019). Ochrona środowiska 2019. Warszawa: GUS.

Hanna, E., Navarro, F.J., Pattyn, F., Dominigues, C.M., Fettweis, X., Ivins, E.R., Nicholls, R., Ritz, C., Smith, B., Tulaczyk, S., Whitehouse, P.L., Zwally, H.J. (2013). Ice-sheet Mass Balance and Climate Change. Nature, Vol. 498, pp. 51-59. DOI: 10.1038/nature12238.

Hoegh-Guldberg, O., Mumby, P.J., Hooten, A.J., Steneck, R.S., Greenfield, P., Gomez, E., Harvell, C.D., Sale, P.F., Edwards, A.J., Caldeira, K., Knowlton, N., Eakin, C.M., Iglesias-Prieto, R., Muthiga, N., Bradbury, R.H., Dubi, A., Hatziolos, M.E. (2007). Coral Reefs Under Rapid Climate Change and Ocean Acidification. Science, Vol. 318, Issue 5857, pp. 1737-1742. DOI: 10.1126/science. 1152509 .

Kabza, M. (2019). Można uniknąć dużych skutków ekonomicznych zmian klimatu. Retrieved from: https://forsal.pl/artykuly/1433827,mozna-uniknac-duzych-skutkow-ekonomicznych-zmian-klimatu.html (access date: 12.10.2019).

KLIMADA (2019). Konsekwencje zmian klimatu. Polityka adaptacyjna rolnictwa do zmian klimatu do roku 2070. Retrieved from: http://klimada.mos.gov.pl/zmiany-klimatu-w-polsce/ konsekwencje-zmian-klimatu/ and: http://klimada.mos.gov.pl/blog/2013/04/15/rolnictwo/ (access date: 5.2.2020).

Kowalczyk, M. (2018). CO zmienia klimat. Jak ocieplenie klimatu zmieni polska wieś? Retrieved from: http://fundacjawspomaganiawsi.pl/jak-ocieplenie-klimatu-zmieni-polska-wies/ (access date: 4.12.2018).

Kundzewicz, W., Kozyra, J. (2011). Ograniczanie wpływu zagrożeń klimatycznych w odniesieniu do rolnictwa i obszarów wiejskich. Polsh Journal of Agronomy, No. 7, pp. 68-81. 
Kurtyka, M. (2020). Ministerstwo Klimatu: Neutralność klimatyczna to koszt 400 mld euro. Retrieved from: https://biznesalert.pl/ministerstwo-klimatu-neutralnosc-klimatyczna-koszt-in-terpelacja-poselska-energetyka/ (access date: 24.1.2020).

Lenton, T.M., Rockström, J., Gaffney, O., Rahmstorf, S., Richardson, K., Steffen, W., Schellnhube, H.J. (2019). Climate Tipping Points - Too Risky to Bet Against. Nature, Vol. 575(7784), pp. 592595. DOI: 10.1038/d41586-019-03595-0.

Moore, J.W. (2014). Kryzys: ekologiczny czy ekologicznie-świtowy?. Praktyka Teoretyczna, No. 4(14), pp. 259-267.

Nelson, G.C., Rosegrant, M.W., Koo, J., Robertson, R., Sulser, T., Zhu, T., Rinigler, C., Msangi, S., Palazzo, A., Batka, M., Magalhaes, M., Valmonte-Santos, R., Ewing, M., Lee, D. (2009). Climate Change: Imact on Agriculture and Costs of Adaptation. Washington: International Food Police Research Institute. DOI: 10.2499/0896295354.

Parmesan, C. (2006). Ecological and Evolutionary Respnsens to Recent Climate Change. Annual Review of Ecology, Evolution and Systematics, Vol. 37(1), pp. 637-669. DOI: 10.1146/annu-rev.ecolsys.37.091305.110100

Polacy wobec zmian klimatu. Komunikat z badań (2018). Komunikat z badań, No. 158/2018. Warszawa: Centrum Badania Opinii Społecznej.

Polityka klimatyczna - fakty i mity (2018). Warszawa: Heinrich Böll Stiftung.

Popkiewicz, M. (2013). Fakty i mity. Mit: nauka nie jest zgodna w temacie globalnego ocieplenia. Retrieved from: https://naukaoklimacie.pl/fakty-i-mity/mit-nauka-nie-jest-zgodna-w-temacie-globalnego-ocieplenia-7 (access date: 30.7.2013).

Popkiewicz, M., Kardaś, A., Malinowski, S. (2019). Nauka o klimacie. Warszawa: Post FACTUM. Rogala, B. (2020). To rolnikom powinno najbardziej zależeć na ochronie klimatu, bo najmocniej odczuja zmiany - wywiad z dr. Zbigniewem Karaczunem. Retrieved from: https://300gospodarka. pl/wywiady/to-rolnicy-najmocniej-ze-wszystkich-odczuja-skutki-zmian-klimatu-wywiad-z-dr-zbigniewem-karaczunem (access date: 14.2.2020).

Sadura, P., Murawska, K., Włodarczyk, Z. (2017). Wieśs w Polsce 2017: diagnoza i prognoza. Warszawa: Fundacja Wspomagania Wsi.

Sánchez-Bayo, F., Wyckhuys, K.A.G. (2019). Worldwide Decline of the Entomofauna: A Review of its Drivers. Biological Conservation, Vol. 232, pp. 8-27.

Saunois, M., Jackson, R.B., Bousquet, P., Poulter, B., Canadell, J.G. (2016). The Growing Role of Methane in Anthropogenic Climate Change. Environmental Research Letters, Vol. 11, No. 12:120207. DOI: 10.1088/1748-9326/11/12/120207.

Sękowski, M. (2014). Uwarunkowania produkcji roślinnej w kontekście zmian klimatycznych. Radom: Centrum Doradztwa Rolniczego w Brwinowie Oddział w Radomiu.

Steffen, W., Rockström, J., Richardson, K., Lenton, T.M., Folke, C., Liverman, D., Summerhayes, C., Barnosky, A.D., Cornell, S., Crucifix, M., Donges, J.F., Fetzer, I., Lade, S.J., Scheffer, M., Winkelmann, R., Schellnhuber, H.J. (2018). Trajectories of the System in the Anthropocene. PNAS, Vol. 115, Issue 33, pp. 8252-8259. DOI: 10.1073/pnas.1810141115.

Stroeve, J.C., Kattsov, V., Barrett, A., Serreze, M., Pavloya, T., Holland, M., Meier, W.N. (2012). Trends in Arcticseaiceextent from CMIP5, CMIP3 and Observations. Geophisical Research Letter, Vol. 39, Issue 16. L16502. DOI:10.1029/2012GL05267.

Szafraniec, K., Boni, K. (ed.) (2011). Młodzi 2011. Warszawa: Kancelaria Prezesa Rady Ministrów.

Szymański, D. (2020). Walczymy z jednym kryzysem, a już do Polski zawitat drugi. Retrieved from: https://businessinsider.com.pl/finanse/handel/susza-w-polsce-wplynie-na-ceny-warzywi-owocow/25c8mxt (access date: 15.4.2020). 
Tubiello, F.N., Soussana, J.F., Howden, S.M. (2007). Crop and Pasture Response to Climate Change. PNAS, Vol. 104, No. 50, pp. 19686-19690, DOI: 10.1073/pnas.0701728104.

Weather, Climate \& Catastrophe Insight. 2019 Annual Report (2019). Aon Empower Results, Chicago. Retrieved from: http: //thoughtleadership.aon.com/Documents/20200122-ifnatcat2020. pdf?utm_source $=$ ceros\&utm_medium $=$ storypage\&utm_campaign $=$ natcat $20(\mathrm{ac}-$ cess date: 24.1 .2020$)$.

WMO (2019a). Greenhouse Gas Bulletin: The State of Greenhouse Gases in the AtmosphereBased on Global Observations through 2018, No. 15/25. Retrieved from: https://library.wmo.int/ doc_num.php?explnum_id=10100 (access date: 30.11 .2019 ).

WMO (2019b). Provisional Statement on the State of the Global Climate in 2019. WMO.

Yao, T., Thompson, L., Yang, W., Yu, W., Gao, Y., Guo, X., Yang, X., Duan, K., Zhao, H., Xu, B., Pu, J., Lu, A., Xiang, Y., Kattel, D.B., Joswiak, D. (2012). Different glacier status with atmospheric circulations in Tibetan Plateau and surroundings. Nature Climate Change, Vol. 2, pp. 663-667.

Zagrożenie susza - raport kwiecień 2020 r. Retrieved from: https://stopsuszy.pl/zagrozenie-susza-raport-kwiecien-2020-r/ (access date: 4.5.2020).

Zmiany klimatu zagrażaja rolnictwu w UE. Retrieved from: https://www.pb.pl/zmiany-klimatu-za-grazaja-rolnictwu-w-ue-969440 (access date: 4.9.2019). 


\title{
WPŁYW ZMIANY KLIMATU NA GLOBALNY STAN ŚRODOWISKA I ROLNICTWA W OPINII MŁODZIEŻY WIEJSKIEJ WOJEWÓDZTWA PODKARPACKIEGO
}

\begin{abstract}
Abstrakt
Celem artykułu jest poznanie opinii młodzieży wiejskiej w zakresie jej świadomości dotyczacej zmiany klimatu $i$ wptywu tej zmiany na rolnictwo oraz na ich podstawie stwierdzenie, czy młodzież ta posiada odpowiednia wiedze dotyczaca globalnych zmian klimatu.

Cel ten wynika z faktu, że świat coraz dotkliwiej odczuwa skutki zmiany klimatu zwiazane z czestszym wystepowaniem ekstremalnych zjawisk pogodowych powiazanych ze wzrostem temperatur powietrza, występowaniem okresowych fal susz i upałów, gwattownych huraganów czy topnieniem lodowców. Zmiany te, zaczynajace już przybierać etap sytuacji kryzysowej, zwiazane sa gtównie $z$ emisja gazów cieplarnianych, a przede wszystkim dwutlenku wegla, za która odpowiedzialność ponosi przede wszystkim ludzkość. Konieczne zatem staje sie zwiększenie świadomości mieszkańców obszarów wiejskich, począwszy od dzieci i młodzieży, która $w$ najbliższej przyszłości będzie sterować rozwojem regionów i świata, jak wielkim zagrożeniem dla nich, dla rolnictwa, a w konsekwencji dla bezpieczeństwa żywnościowego i zdrowia ludzkości sa postepujące zmiany klimatu. Młodzież obecnie potrzebuje odpowiedniego wsparcia od naukowców oraz nauczycieli, którzy pomoga jej zrozumieć i uświadomia, jak wielka sprawa jest konieczność podjęcia działań adaptacyjnych związanych z eliminowaniem zagrożeń wynikajacych ze zmiany klimatu, uprawa gatunków roślin bardziej odpornych na zaistniałe warunki klimatyczne, ochrona bioróżnorodności, zasobów wodnych, lasów i gleby.

$W$ artykule przedstawiono przyczyny oraz konsekwencje zmian klimatu $w$ świetle badań oraz opinii spoleczeństwa, wplyw zmian klimatu na rolnictwo oraz opinie badanej młodzieży wiejskiej z woj. podkarpackiego na temat wspótczesnych zmian klimatu.
\end{abstract}

Słowa kluczowe: zmiany klimatu, globalne ocieplenie, rolnictwo, młodzież.

Accepted for print: 29.09.2020.

Unless stated otherwise all the materials on the website are available under the Creative Commons Attribution 4.0 International license.

Some rights reserved to the Institute of Agricultural and Food Economics - National Research Institute.

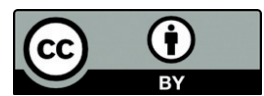

